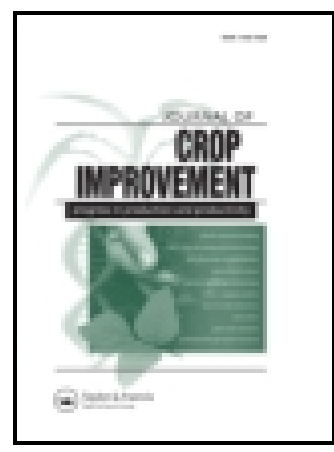

Journal of Crop Improvement

ISSN: 1542-7528 (Print) 1542-7536 (Online) Journal homepage: https://www.tandfonline.com/loi/wcim20

\title{
Legume seed production for sustainable seed supply and crop productivity: case of groundnut in Tanzania and Uganda
}

\section{Essegbemon Akpo, Geoffrey Muricho, Gerald Alex Lukurugu, Hellen Opie,} Chris O. Ojiewo \& Rajeev Varshney

To cite this article: Essegbemon Akpo, Geoffrey Muricho, Gerald Alex Lukurugu, Hellen Opie, Chris O. Ojiewo \& Rajeev Varshney (2020): Legume seed production for sustainable seed supply and crop productivity: case of groundnut in Tanzania and Uganda, Journal of Crop Improvement, DOI: $10.1080 / 15427528.2020 .1740368$

To link to this article: https://doi.org/10.1080/15427528.2020.1740368

Published online: 26 Mar 2020.

Submit your article to this journal $₫$

View related articles

View Crossmark data $\nearrow$ 


\title{
Legume seed production for sustainable seed supply and crop productivity: case of groundnut in Tanzania and Uganda
}

\author{
Essegbemon Akpo a,b Geoffrey Muricho ${ }^{a}$, Gerald Alex Lukurugu'c, Hellen Opie ${ }^{d}$, \\ Chris O. Ojiewo ${ }^{a}$, and Rajeev Varshney ${ }^{a}$ \\ aGenetic Gains, International Crops Research Institute for the Semi-Arid Tropics, Patancheru, India; \\ bEcole de Gestion et de Production Végétale et Semencière, Université Nationale d'Agriculture, Kétou, \\ Benin; 'Naliendele Agricultural Research Center, Tanzania Agricultural Research Institute, Mtwara, \\ Tanzania; ${ }^{d}$ National Agricultural Research Organization, National Semi-Arid Resources Research \\ Institute, Soroti, Uganda
}

\begin{abstract}
Improving agricultural productivity and production is a prerequisite to sustain rural livelihoods in developing countries of sub-Saharan Africa (SSA). This requires increased use of quality seed of improved and well-adapted crop varieties. Legumes are particularly critical in ensuring food and nutritional securities of the majority of farming households. However, their productivity has been constrained because of limited availability of quality seed, jeopardizing henceforth food security and rural livelihoods. The lack of interest in production of legume seeds by potential seed producers, especially the private sector, is attributable to limited information on the cost and profitability of producing these seeds. Using primary data collected from Tanzania and Uganda, we analyzed the cost structure of improved groundnut (Arachis hypogaea L.) seed production to assess viability. We adopted cost-benefit analysis framework to evaluate different seed production models. Results showed that groundnut seed price varied between 1 and 2 US\$ kg ${ }^{-1}$ for certified

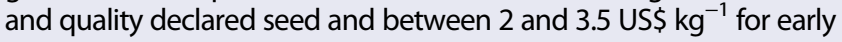
generation seed. Overall, up to $50 \%$ increase in total seed production costs resulted in reduced drop in the gross margin earned. However, when production costs increased by $75-100 \%$, the gross margin dropped by about $18 \%$ and $50 \%$ in Tanzania and in Uganda, respectively. These findings indicated that groundnut seed could be provided to farmers in remote communities at an affordable price while still keeping seed producers profitably in business. Availing these seeds to smallholder producers is a major step in achieving food security and nutritional health in developing countries in SSA.
\end{abstract}

\section{ARTICLE HISTORY}

Received 7 February 2020

Accepted 5 March 2020

\section{KEYWORDS}

Eastern Africa; improved legume varieties; productivity of smallholder farming; seed business viability; seed price; seed production model

\section{Introduction}

Legume crops play a critical role in improving agricultural productivity, food security, and nutritional security of many households in sub-Saharan Africa (SSA) (Lanteri and Quagliotti 1997). Firstly, most of the soils in SSA are

CONTACT Essegbemon Akpo e.akpo@cgiar.org E International Crops Research Institute for the Semi-Arid Tropics, Patancheru, Telangana, 502 324, India

(c) 2020 Informa UK Limited, trading as Taylor \& Francis Group 
nitrogen-deficient and use of commercial inorganic fertilizers to ameliorate this has proven to be an expensive undertaking by the resource-poor smallholders. Therefore, legumes come in handy, as they can replenish soil nitrogen through atmospheric nitrogen fixation in their root nodules. This fertility improvement has spill-over effects, as it goes a long way in improving the productivity of other crops (especially cereals) that are usually grown in rotation or as intercrops with these legumes. Secondly, with increased overall farm productivity, as a result of improved soil fertility through soil nitrogen fixation, household incomes are bound to increase, and poverty is bound to be reduced substantially. Lastly, malnutrition is widespread in SSA and legumes are the cheap and easily available source of protein among the poor rural and urban households. About a third of the children in SSA suffer from stunted growth and the easiest and cheapest way to address this problem is through availability of grain legumes to them.

Despite the critical role that legumes play in assuring the food security and livelihoods of many households in SSA, production of legume grains is limited because of low adoption of high-yielding well-adapted improved legume varieties. Limited availability and accessibility to seeds of improved legume varieties have been mentioned as some of the most constraining factors that have led to low adoption. The legume seed supply-demand paradox is that potential producers of these seeds cite lack of profitability in production of these seeds, while on the other hand, grain producers have attributed limited adoption of these superior seeds to high prices (FAO 2010). This is not withstanding the fact that past studies have emphasized the substantial contributions of quality seed in agriculture and crop production (McGuire and Sperling 2013; Akpo et al. 2014). In fact, it has been argued that seed is the most precious of all the resources in the hands of resource-poor farmers (Akpo 2013). The limited adoption is further reinforced by the self-pollinated nature of legume crops. This is contrary to hybrid varieties that have a clear productivity difference between recycled and newly bought seed. With limited demand for new seed from grain producers, the per unit cost of producing this seed across time is argued to be prohibitive, given the heavy initial non-variable fixed capital investment. However, there is not much empirical evidence to demonstrate profitability and commercial viability of investing in legume seed production.

Like cereals, legume seed production and dissemination to smallholder farmers in remote communities have extensively evolved during the past three decades across countries in SSA. From full state control to private sector involvement, the context of seed supply varies from one country to another and is crop-specific. These different seed production models are aimed at stimulating seed demand through reduction in production costs that can be translated into reduced price seed to smallholder grain producers in remote areas where many of them fall under the poverty line and food insecurity. However, 
available evidence shows that more than $80 \%$ of smallholder farmers are still unable to use improved seed and access planting materials from various informal sources (GIZ 2014; McGuire and Sperling 2013, 2016).

To improve the current trends of smallholder farmers' use of seed of improved varieties, various seed production and delivery models have been developed, tested, and implemented. These strategies have targeted not only seed accessed directly by farmers but also the early generation seeds $\left(\mathrm{EGS}^{1}\right)$. More seed production stakeholders have been sensitized and encouraged to actively participate in the value chain. For example, smallholder farmers in rural areas have been encouraged and facilitated to produce seed of selected improved varieties, leading to several empirical studies that have analyzed profitability of seed production by smallholder farmers (Katungi et al. 2011; Pal et al. 2016; Omonona 2006).

To make seeds of improved varieties readily available for smallholder farmers and enhance food security in remote communities, there is a need to use seed production models that lower production costs and ultimately seed price. While many studies reported the high seed price as a major challenge hindering small farmers from using improved varieties of a wide variety of crops (McGuire and Sperling 2013; Akpo et al. 2012; McGuire and Sperling 2016; Monyo and Varshney 2016; Bishaw, Makkawi, and Niane 2009), there is a knowledge gap regarding a comprehensive analysis of seed production models that brings down seed price. This research fills in these knowledge gaps by analyzing groundnut seed production costs from different models, using primary data collected in Tanzania and Uganda. In this paper, we analyze the cost structure of different seed classes of groundnut in the two countries using cost-benefit analysis (CBA) framework. The seed classes considered are breeder seed, foundation seed, ${ }^{2}$ certified seed, and quality declared seed (QDS). ${ }^{3}$ The analysis is conducted based on actors along the seed value chains and production arrangements. ${ }^{4}$ It is plausible to assume that different seed classes and production arrangements may be associated with distinct production costs that could avail quality seed to grain farmers at different prices. Therefore, understanding the cost structure of different seed classes in different production arrangements is likely to shed light on interventions that can unlock private-sector investments in groundnut seed production, thereby enhancing sustainable food security.

\section{Methodology}

\subsection{Study area and context}

This study is based on groundnut seed production data in two Eastern Africa countries of Tanzania and Uganda. These two countries were target geographies of Tropical Legume Project. Groundnut is a major cash legume crop 
for smallholder farming and livelihood systems in the two countries. For example, in 2017, a total of 978,867 tons and 215,152 tons of groundnut were produced in Tanzania and Uganda, respectively (FAOSTAT 2019). More than $80 \%$ of this production is still delivered by smallholder farmers in both countries (Mangasini et al. 2014). In each county, the study was conducted in the main agro-ecologies of groundnut production and where seed producers are located, i.e. Eastern and Northern regions in Uganda, Southern zone, Lake zone, and central zone in Tanzania.

\subsection{Sampling of seed producers}

Different categories of seed producers in each study country were included in the sample frame. Research institutes, seed companies, farmer seed-producing groups and cooperatives, and individual seed entrepreneurs were sampled. Whenever enough seed producers existed in each sample category, a minimum of 10 seed producers were randomly selected and interviewed. In categories where there were 10 or fewer producers, all of them were sampled. As different plots may carry different groundnut varieties, the lowest sampling unit was the plot level. For example, for seed company with two seed production plots, data were collected on each individual plot. A total of 127 plots were sampled in the two countries, i.e. 49 and 78 plots in Tanzania and Uganda, respectively.

\subsection{Data collection}

This study utilizes data collected from different categories of actors involved in groundnut seed production. They were researchers, seed companies, individual seed entrepreneurs, farmer groups, and cooperatives for different seed classes (breeder, foundation, certified, and QDS). We also collected data on different groundnut seed production and delivery models (self-production; contract production), area planted, production quantities, and labor and nonlabor inputs that went into production. Some of these costs included land rental value, cost of various nonlabor inputs (EGS, herbicide, insecticide), labor cost of various activities (land preparation, planting, weeding, pest and insect control, harvesting, threshing, packaging, transport, etc.), data on seed selling price, storage costs, and other relevant costs.

\subsection{Data analysis}

The initial data, collected from the questionnaires the respondents submitted to, were entered in Statistical Package for the Social Sciences (SPSS) software for data management and analysis. Exploratory analysis of data using simple descriptive statistics (means and frequencies) was conducted to characterize groundnut seed production in the two study countries. Gross margins of different groundnut 
seed production models were computed using Eqn. (1). These gross margins were compared across the seed production models.

$$
M G_{i}=T R_{i}-T C_{i}
$$

where $M G_{i}=$ the gross margins (US\$/ha)

$T R_{i}=$ the total revenues (US\$/ha)

$T C_{i}=$ the total costs (US\$/ha)

The total costs were categorized into two main groups of labor and nonlabor cost items. On the other hand, total revenue was computed as the yield of seed $(\mathrm{kg} / \mathrm{ha}$ ) multiplied by per unit selling price of harvested seed (US\$/kg). After computing the gross margins for each seed production model, we conducted sensitivity analysis to see how the profitability (proxied by gross margins) of seed production will respond to increase in seed production costs. We held all else constant and increased the cost of production by $10 \%$, $25 \%, 50 \%, 75 \%$, and then $100 \%$. Corresponding gross margins are computed under the five scenarios of varying groundnut seed production costs (increase by $10 \%, 25 \%, 50 \%, 75 \%$, and $100 \%$ ).

We stretched the analysis further beyond simple characterization of groundnut seed production by conducting the financial analysis of the different groundnut production models using the CBA framework following the study by Gittinger (1982). This latter analysis was intended to derive knowledge on the profitability and commercial viability of the different groundnut seed production and delivery models in the study countries. The CBA framework assists in answering two critical investment questions, i.e. if the investment is viable or not and if faced with multiple projects to choose from, then which one is more viable - in our case, here we refer to seed production and delivery models. This framework has five main variants:

- Benefit-Cost Ratio (BCR)

- Incremental Cost-Benefit Ratio (ICBR)

- Net Present Value (NPV)

- Payback Period (PP)

- Internal Rate of Return (IRR)

In the current study, we compute the BCR and conduct sensitivity analysis to assess the robustness of the investment viability indicators under different cost and revenue scenarios. The BCR is computed as a ratio of the present value of investment benefits (revenue) to present the value of investment costs. The present values of project revenues and costs are computed as discounted values of revenues and costs using the discount rate. The discounting rate is usually the market interest rate of savings or lending rates. The BCR is mathematically represented as 


$$
\mathrm{BCR}=\frac{\left[\frac{\sum B_{t}}{(1+r)^{t}}\right]}{\left[\frac{\sum C_{t}}{(1+r)^{t}}\right]}
$$

where $B_{i}$ is the project benefits (revenue) at time $t$,

$C_{i}$ is the project costs at time $t$,

$r$ is the discounting factor (market interest rate on borrowed funds) at time $t$.

There is no one single rule of getting the right discount rate. In the current study, we rather use the interest rate on bank savings account in each country, i.e. $6 \%$ in Tanzania and 9\% in Uganda.

The final decision is based on the conclusion that if

$\mathrm{BCR}<1$ : then costs exceed benefits and the investment venture is not viable,

$\mathrm{BCR}=1$ : the costs are exactly equal to benefits and this venture can proceed with caution,

$\mathrm{BCR}>1$ : the investment costs are less than benefits and therefore the investment is viable.

Basically, this approach assists in appraising the investment at hand and requires three critical sets of data, i.e. the project costs, benefits and discount rate, as shown in Eqn. (1).

Finally, because the two countries use different currencies, we have used their equivalent in US\$ to harmonize and facilitate readership of this paper. During the period of data collection, the exchange rates for 1 USD were Tsh 2280 for Tanzania and Ush 3700 for Uganda.

\subsection{Limitations to this study}

Some of the groundnut seed production and delivery models did not have enough respondents to sample from, forcing the study to use the whole population. This has a limitation on the validity of inferences derived from the computed statistics. Also, not all models of seed production were represented for the different seed classes in both countries and, therefore, we were not able to consider all possible cases in this study.

\section{Results}

\subsection{Seed production models}

The analysis of data collected showed two main groundnut seed production and delivery models, i.e. self-seed production and contract seed production and delivery models (Table 1). Under self-seed production model, we found 
Table 1. Seed production models.

\begin{tabular}{|c|c|c|c|c|c|c|c|c|}
\hline \multirow[b]{2}{*}{ Actors } & \multicolumn{2}{|c|}{ Breeder } & \multicolumn{2}{|c|}{$\begin{array}{c}\text { Foundation } \\
\text { seed }\end{array}$} & \multicolumn{2}{|c|}{ Certified seed } & \multicolumn{2}{|c|}{$\begin{array}{c}\text { Quality declared } \\
\text { seed }\end{array}$} \\
\hline & Self & Contract & Self & Contract & Self & Contract & Self & Contract \\
\hline Farmer groups and cooperatives & Not & No & No & Yest & Yes & Yes & Yes & No \\
\hline Individual seed entrepreneurs & No & No & Yes & No & Yes & No & Yes & No \\
\hline Seed companies & No & No & Yes & Yes & Yes & Yes & No & No \\
\hline Research institutes & Yes & No & No & Yes & No & No & No & Yes \\
\hline
\end{tabular}

†Yes indicates the case applies. No indicates not applicable.

about five sub-models of producing and delivering different groundnut seed classes. First, breeder seed was the seed class produced only under self-seed production and delivery model, with no production of this seed class under the contractual arrangement model. Under this self-seed production and delivery of breeder seed, we found that the breeder produced the seed at the research station/site with his/her own resources (labor and nonlabor inputs). Secondly, apart from the breeder seed, the breeder also produced his/her own foundation seed at the research station without contracting. Thirdly, seed companies also produced their own seed, i.e. foundation and certified seeds, with varying levels on inputs, production, and thus profitability. These companies used their own labor and nonlabor inputs, and in cases where they do not produce their own foundation seed, they bought this foundation seed either from the producing breeder or from another company. Lastly, we also found that farmers produced their own QDS seed in the communities where they live. QDS was a recent seed class introduced to enhance access to seed of improved varieties to farmers in remote areas. Farmer groups or cooperatives or individual seed entrepreneurs or local seed businesses (dedicated term in Uganda) produced seeds that they avail to fellow farmers in their communities. The quality seed produced with light quality check could not be marketed beyond the lowest administrative unit where it was produced. The EGS used to produce QDS could either be certified or foundation seed received from research institutes or seed companies.

On the other hand, contractual groundnut seed production did not involve breeder seed, but instead, it was only for foundation, certified, and QDS. First, we found that foundation seed was only produced under contractual arrangement by breeders, who contract selected and trained farmers to produce this seed class and under close supervision. In Tanzania, these contracted seed producers were usually farmer groups, whereas in Uganda, they were individual seed entrepreneur farmers. Seed companies also produced certified seed through trained and experienced contracted individual seed-producing entrepreneurs or contracted farmer groups. In this arrangement, the seed companies provided foundation seed to the contracted entities and supervised the production process. In most cases, QDS 
produced under this contractual arrangement was used for setting up demonstrations and various awareness creation activities like field days within the farming communities.

\subsection{Characterization of groundnut seed production in Tanzania and Uganda}

In this section, we present the general characteristics of seed production in Tanzania and Uganda. Within the sample, the average plot size of seed production was 0.87 ha $(P>0.05)$ in Tanzania (Table 2$)$. On average, farmer organizations obtained significantly higher yield $(1363 \mathrm{~kg} / \mathrm{ha})$ compared with research institute $(1101 \mathrm{~kg} / \mathrm{ha})$ and individual seed entrepreneurs $(815 \mathrm{~kg} /$ ha). In Uganda, the size of the sampled seed production plot was 0.69 ha. Farmer organizations and individual seed entrepreneurs owned significantly smaller plot size (about $0.56 \mathrm{ha}$ ) compared with research institute. The average yield in Uganda was $852 \mathrm{~kg} / \mathrm{ha}$ (Table 2). Farmer organizations and individual seed entrepreneurs had a statistically similar yield.

On average, farmer organizations and individual seed entrepreneurs sold QDS at 1 USD in Tanzania, while certified seed that seed company produces was sold at 2.2 USD (Table 3). At the same time, foundation seed that farmer organizations produced was purchased at 3.5 USD, which was three times that of QDS. Breeder seed that research institute produces was sold at twice the price of certified seed at 4.4 USD.

In Uganda, QDS that farmers produced was sold at 1.6 USD on average against 0.9 USD for certified seed and 1.9 USD for foundation seed. Individual seed entrepreneurs sold foundation and QDS at about 2 USD and 1.6 USD,

Table 2. Average plot size and yield.

\begin{tabular}{|c|c|c|c|c|c|}
\hline $\begin{array}{l}\text { Categories of seed } \\
\text { producers }\end{array}$ & $\begin{array}{l}\text { Average plot } \\
\text { size (ha) }\end{array}$ & $\begin{array}{c}\text { Average } \\
\text { yield }(\mathrm{kg} / \mathrm{ha})\end{array}$ & $\begin{array}{l}\text { Categories of seed } \\
\text { producers }\end{array}$ & $\begin{array}{l}\text { Average plot } \\
\text { size (ha) }\end{array}$ & $\begin{array}{c}\text { Average } \\
\text { yield }(\mathrm{kg} / \mathrm{ha})\end{array}$ \\
\hline Tanzania & & & Uganda & & \\
\hline $\begin{array}{l}\text { Farmer groups and } \\
\text { cooperatives (15) }\end{array}$ & $0.88(0.66) \mathrm{a}$ & 1363(676) a & $\begin{array}{l}\text { Farmer groups and } \\
\text { cooperatives (44) }\end{array}$ & $0.55(0.32) \mathrm{a}$ & $914(538) \mathrm{a}$ \\
\hline $\begin{array}{l}\text { Individual seed } \\
\text { entrepreneurs (22) }\end{array}$ & $0.89(0.89)$ a & $815(389) b$ & $\begin{array}{l}\text { Individual seed } \\
\text { entrepreneurs (27) }\end{array}$ & $0.56(0.32) \mathrm{a}$ & 795(646) a \\
\hline $\begin{array}{l}\text { Private seed } \\
\text { companies }(2) \dagger\end{array}$ & $0.80(0.00)$ & $938(88)$ & $\begin{array}{l}\text { Private seed } \\
\text { companies (2)† }\end{array}$ & $3.6(0.56)$ & $1313(371)$ \\
\hline Research institutes (10) & $0.85(0.33) \mathrm{a}$ & $1101(74) a b$ & Research institutes (5) & $1.48(0.63) b$ & $436(182) a$ \\
\hline Average (49) & $0.87(0.70)$ & $1046(508)$ & Average (78) & $0.69(0.63)$ & $852(571)$ \\
\hline F-statistic; $P$ value & $\begin{array}{l}0.009 \\
P=0.991\end{array}$ & $\begin{array}{l}6211 \\
P=0.004\end{array}$ & F-statistic; $P$ value & $\begin{array}{l}16.828 \\
P=0.000\end{array}$ & $\begin{array}{l}1.731 \\
P=0.184\end{array}$ \\
\hline
\end{tabular}

Aver. is average. FS is foundation. QDS: quality declared seed. CS is certified seed. BS is breeder seed. Bold figures in brackets indicate the number of plots sampled. Non-bold figures in brackets are standard deviation. $\dagger$ indicates the sample size was too low and was not considered for the statistical analysis. For the same column, values followed by the same letter are not significantly different as established by the Tukey-HSD test $(P<0.05)$. 
Table 3. Average seed selling price.

\begin{tabular}{lcclcc}
\hline \multicolumn{2}{l}{$\begin{array}{l}\text { Categories of seed producers and seed } \\
\text { classes }\end{array}$} & $\begin{array}{c}\text { Aver. price } \\
\text { (US\$) }\end{array}$ & $\begin{array}{c}\text { Categories of seed producers and } \\
\text { seed class }\end{array}$ & $\begin{array}{c}\text { Aver. price } \\
\text { (US\$) }\end{array}$ \\
\hline Tanzania & FS (6) & $3.51(0.0)$ & $\begin{array}{l}\text { Uganda } \\
\text { Farmer groups \& }\end{array}$ & FS (13) & $1.93(0)$ \\
Farmer groups and & CS (0) & - & cooperatives (44) & CS (7) & $0.89(0.32)$ \\
$\quad$ cooperatives (15) & QDS (9) & $1.04(0.28)$ & & QDS (24) & $1.61(0.0)$ \\
& FS (0) & - & Individual seed & FS (13) & $1.93(0.0)$ \\
Individual seed & QDS (22) & $0.97(0.20)$ & entrepreneurs (27) & QDS (14) & $1.61(0.0)$ \\
$\quad$ entrepreneurs (22) & FS (0) & - & Private seed companies (2) & FS (2) & $1.31(0.33)$ \\
Private seed companies (2) & CS (2) & 2.19 & & CS (0) & - \\
Research institutes (10) & BS (10) & $4.39(0)$ & Research institutes (5) & BS (5) & $2.57(0.0)$ \\
\hline
\end{tabular}

Aver. is average. FS is foundation. CS is certified seed. QDS: quality declared seed. BS is breeder seed. Bold figures in brackets indicate the number of plots sampled. Non-bold figures in brackets are standard deviation.

respectively. Under contract, farmer groups and cooperatives sold certified seed back to seed companies at 0.9 USD, which was under the price they market QDS. Researchers sold breeder seed themselves at 2.6 USD (Table 3).

\subsection{Variation of seed costs in contracting vs. self-production scheme}

In both Tanzania and Uganda, breeder seed production was conducted by the researchers themselves. While the production cost per ha varied between 781 USD and 868 USD in both countries, the gross margin per ha in Tanzania was higher than that in Uganda (US\$ 253 per ha). Likewise, the cost of producing $1 \mathrm{~kg}$ breeder seed of groundnut in Uganda (US\$ 2.3) was about thrice that in Tanzania (Table 4).

On average, the gross margin per ha for foundation seed production under self-production scheme was 4507 USD per ha, which was around 100 USD higher than that under contract in Tanzania. The cost of producing $1 \mathrm{~kg}$ foundation seed of groundnut under contract scheme was 0.2 USD higher than that in self-production (US\$ 0.4). In Uganda, foundation seed production cost was higher than that in Tanzania and amounts to 0.8 USD.

Certified seed (self-production) was produced at much higher cost in Tanzania (US\$ 1.5), which was three times more expensive than that in Uganda but produced under contract farming. QDS cost on average between 0.4 USD and 0.7 in Tanzania under self-production and contract schemes, respectively. In Uganda, $1 \mathrm{~kg}$ of QDS was produced at around 0.5 in both self-production and contract schemes.

\subsection{Variation in seed cost across main categories of seed producers}

In Tanzania, farmer organizations were the ones used to produce foundation seed of groundnut. On average, the production of 1 ha foundation seed in 


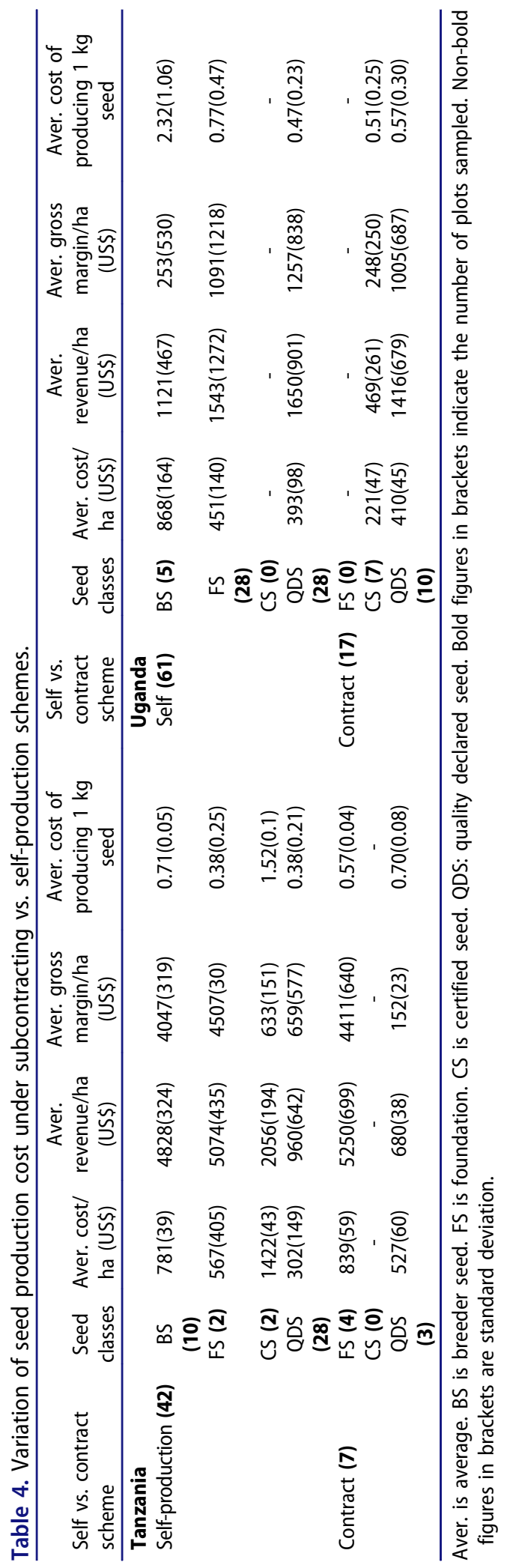


Tanzania costs about 750 USD and yielded a gross margin of about 4440 USD per ha (Table 5). On average, the production of $1 \mathrm{~kg}$ of groundnut foundation seed cost farmer organization 0.5 USD in Tanzania.

In Uganda, farmer groups and cooperatives, individual seed entrepreneurs and private seed companies were all involved in foundation seed production of groundnut. While farmer organizations and individual seed entrepreneurs needed about 425 USD per ha to produce foundation seed of groundnut, private seed companies spent about twice that amount (about 790 USD per ha). However, private seed companies seemed to produce more efficiently, as they had a lower cost than farmer organizations per $\mathrm{kg}$ of foundation seed produced, 0.6 USD against $0.8 \mathrm{USD}$, respectively. Overall, the average gross margin varied between about 940 USD and 1250 USD per ha for all categories of foundation seed producers, with individual seed entrepreneurs making the highest gross margin (US\$ 1253 per ha). In Tanzania, private seed companies produced certified seed at 1.5 USD and earned a gross margin of about 630 USD per ha against 0.5 USD per kg and a gross margin of about 250 USD with farmer organizations in Uganda.

The cost of QDS production by farmer cooperatives and individual seed enterprises was cheaper and the production of 1 ha required expenses below 450 USD in both countries, with lower cost in Tanzania. In both countries, farmer cooperatives earned a higher gross margin, about 800 USD and 1400 USD per ha in Tanzania and Uganda, respectively. To produce $1 \mathrm{~kg}$ of QDS, farmers spent about 0.4 USD in Tanzania against 0.5 USD in Uganda (Table 5).

\subsection{Overall cost structure of seed production}

Three main components that contributed to seed production cost were land, labor costs, and other nonlabor inputs costs. Across all categories of seed producers and seed classes, land contributed on average about $5 \%$ to seed production cost in Tanzania (Table 6). Input expenses contributed to seed production cost by around $25 \%$. The main component of seed production cost was labor, which made about $70 \%$ of total seed production cost. In Uganda, land cost was still minor in seed production cost, with less than $5 \%$ of total seed cost in most cases. Labor and other capital input costs contributed each to between $40 \%$ and $60 \%$ of seed cost in Uganda. It came out clearly that land was not a major factor in the production of seed of improved varieties.

The disaggregated cost components of seed production indicated that EGS, land preparation, weeding, and harvesting labor were the main cost components that made up the seed production cost (Table 7). For all seed classes and in both countries, these cost components contributed to about $80 \%$ of seed production cost. 


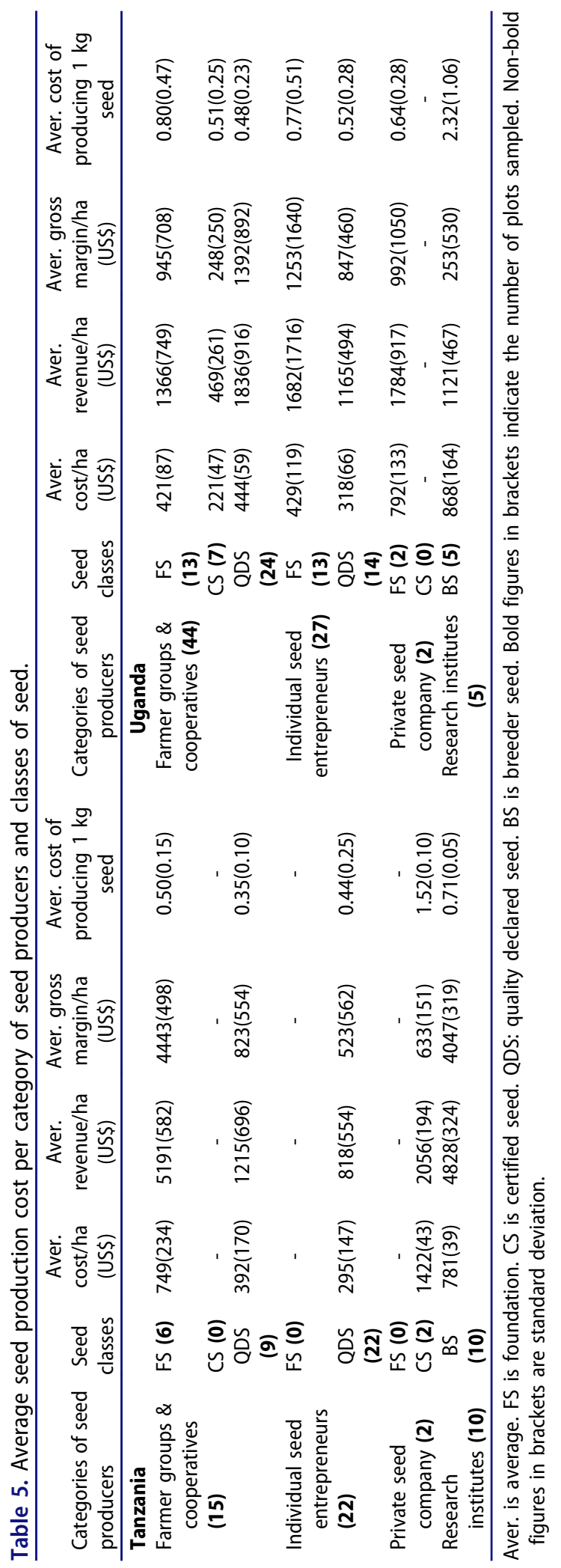




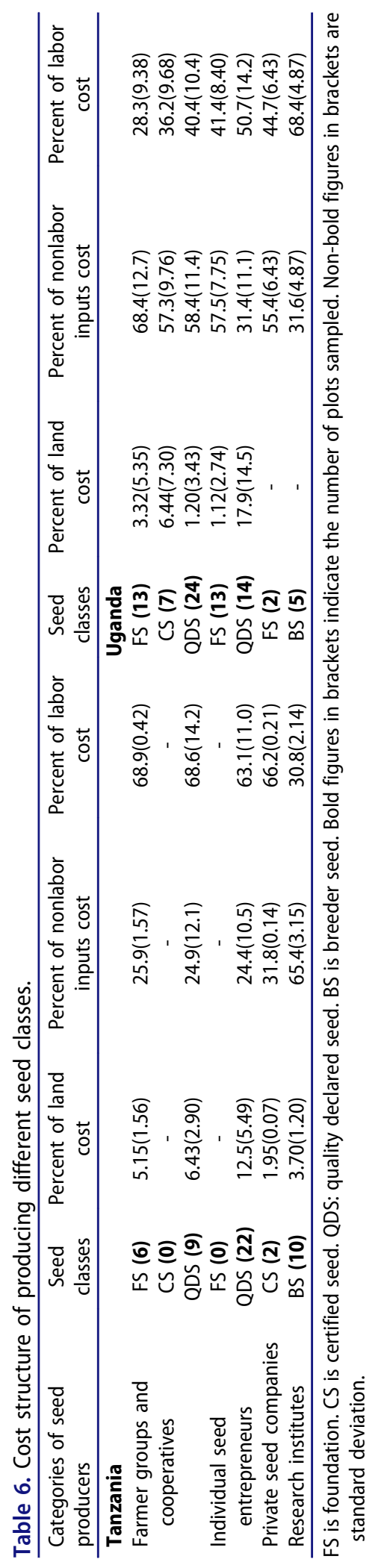


Table 7. Disaggregated cost components of seed production.

\begin{tabular}{|c|c|c|c|c|c|c|c|c|}
\hline $\begin{array}{l}\text { Detailed cost } \\
\text { components }\end{array}$ & $\begin{array}{l}\text { Aver. cost } \\
\text { (US\$) }\end{array}$ & Percent & $\begin{array}{l}\text { Aver. cost } \\
\text { (US\$) }\end{array}$ & Percent & $\begin{array}{l}\text { Aver. cost } \\
\text { (US\$) }\end{array}$ & Percent & $\begin{array}{l}\text { Aver. cost } \\
\text { (US\$) }\end{array}$ & Percent \\
\hline Tanzania & \multicolumn{2}{|c|}{ Breeder seed } & \multicolumn{2}{|c|}{ Foundation seed } & \multicolumn{2}{|c|}{ Certified seed } & \multicolumn{2}{|c|}{$\begin{array}{l}\text { Quality declared } \\
\text { seed }\end{array}$} \\
\hline Land & 30 & 3.58 & 37.5 & 4.56 & 27.5 & 1.93 & 32.5 & 7.73 \\
\hline Fertilizer & 175 & 21.3 & 0 & 0 & 0 & 0 & 0 & 0 \\
\hline Packaging material & 5 & 0.67 & 27.5 & 3.45 & 122.5 & 8.67 & 10 & 2.19 \\
\hline Pesticides & 0 & 0 & 0 & 0 & 0 & 0 & 2.5 & 0.64 \\
\hline Seed & 330 & 40 & 167.5 & 21 & 330 & 23.1 & 57.5 & 14.1 \\
\hline $\begin{array}{l}\text { Fertilizer application } \\
\text { labor }\end{array}$ & 22.5 & 2.67 & 0 & 0 & 0 & 0 & 0 & 0 \\
\hline Grading labor & 0 & 0 & 2.5 & 0.25 & 40 & 2.89 & 10 & 2.52 \\
\hline Harvest labor & 50 & 6.12 & 65 & 8.17 & 132.5 & 9.25 & 55 & 13.2 \\
\hline $\begin{array}{l}\text { Insecticide } \\
\text { application labor }\end{array}$ & 0 & 0 & 0 & 0 & 0 & 0.08 & 2.5 & 0.34 \\
\hline $\begin{array}{l}\text { Land preparation } \\
\text { labor }\end{array}$ & 42.5 & 5.02 & 72.5 & 8.89 & 22.5 & 1.54 & 100 & 24.1 \\
\hline Packaging labor & 0 & 0 & 27.5 & 0 & 20 & 0 & 2.5 & 0 \\
\hline Planting labor & 45 & 5.33 & 80 & 10.1 & 45 & 3.08 & 25 & 6.21 \\
\hline Security/guard & 12.5 & 1.43 & 0 & 0 & 87.5 & 6.17 & 5 & 1.08 \\
\hline Seed certification & 60 & 7.15 & 0 & 0 & 277.5 & 19.5 & 0 & 0 \\
\hline Weeding labor & 45 & 5.33 & 45 & 5.47 & 45 & 3.08 & 47.5 & 11.3 \\
\hline Transportation & 2.5 & 0.29 & 30 & 3.8 & 27.5 & 1.93 & 22.5 & 5.22 \\
\hline $\begin{array}{l}\text { Threshing, } \\
\text { winnowing labor }\end{array}$ & 7.5 & 1.06 & 247.5 & 30.8 & 247.5 & 17.3 & 45 & 10.7 \\
\hline \multicolumn{9}{|l|}{ Uganda } \\
\hline Land & - & - & 10 & 2.03 & 15 & 5.95 & 25 & 5.38 \\
\hline Fertilizer & 0 & 0 & 17.5 & 3.29 & 7.5 & 2.32 & 2.5 & 0.38 \\
\hline Packaging material & 5 & 0.46 & 7.5 & 1.4 & 2.5 & 1.31 & 7.5 & 1.42 \\
\hline Pesticides & 0 & 0 & 5 & 1.19 & 0 & 0 & 0 & 0.07 \\
\hline Seed & 265 & 28.7 & 245 & 47.5 & 112.5 & 41.9 & 190 & 40.5 \\
\hline $\begin{array}{l}\text { Fertilizer application } \\
\text { labor }\end{array}$ & 0 & 0 & 2.5 & 0.42 & 2.5 & 0.77 & 0 & 0.08 \\
\hline Grading labor & 12.5 & 1.41 & 0 & 0.05 & 0 & 0 & 0 & 0.15 \\
\hline Harvest labor & 117.5 & 12.9 & 42.5 & 8.52 & 10 & 3.38 & 40 & 8.54 \\
\hline $\begin{array}{l}\text { Insecticide } \\
\text { application labor }\end{array}$ & 0 & 0 & 2.5 & 0.42 & 0 & 0 & 0 & 0.05 \\
\hline $\begin{array}{l}\text { Land preparation } \\
\text { labor }\end{array}$ & 52.5 & 5.75 & 62.5 & 12.39 & 50 & 18.46 & 80 & 16.85 \\
\hline Packaging labor & 0 & 0 & 0 & 0.05 & 0 & 0 & 0 & 0.08 \\
\hline Planting labor & 67.5 & 7.34 & 45 & 8.57 & 22.5 & 8.52 & 40 & 8.34 \\
\hline Security/guard & 105 & 11.4 & 0 & 0 & 0 & 0 & 2.5 & 0.3 \\
\hline Seed certification & - & - & 2.5 & 0.26 & 0 & - & 0.4 & 0.08 \\
\hline Weeding labor & 227.5 & 24.7 & 62.5 & 12.1 & 37.5 & 14.3 & 67.5 & 14.4 \\
\hline Transportation & 7.5 & 0.91 & 5 & 0.85 & 5 & 1.55 & 5 & 1.22 \\
\hline $\begin{array}{l}\text { Threshing, } \\
\text { winnowing labor }\end{array}$ & 60 & 6.45 & 5 & 0.77 & 2.5 & 0.53 & 5 & 1.1 \\
\hline
\end{tabular}

Aver. is average. -: data not available.

\subsection{Sensitivity analysis of the profitability of groundnut seed production in the event of labor and other capital input costs increase}

For foundation seed and breeder seed, an increase between $10 \%$ and $100 \%$ of labor and other capital input costs did not result in a major drop in the gross margin seed producers earn in Tanzania. Up to $50 \%$ increase of labor and other 
capital input costs resulted in less than 10\% drop in the gross margin earned from breeder and foundation seed production (Table 8). When labor and other capital input costs hit $100 \%$ increase, the gross margin dropped by $16 \%$ for foundation seed and $18 \%$ for breeder seed. For QDS and certified seed, on the other hand, the scenario looked worse. When labor and other capital input costs increased by $50 \%$, the gross margin dropped by $25 \%$ for QDS production. In the event of an increase in labor and other capital input costs of $100 \%$, the gross margin almost dropped by $50 \%$ for QDS. For certified seed, a 50\% increase in labor and other capital input costs resulted in negative gross margin of 60 USD per ha. A 100\% increase in labor and other capital input costs resulted in negative gross margin of more than 750 USD per ha.

In Uganda, an increase in the labor and other capital input costs of $100 \%$ induced a drop in the gross margin earned between 30\% and 40\% for foundation seed and QDS for farmer groups and individual seed enterprises (Table 8). Certified seed farmer cooperatives registered a $40 \%$ gross margin drop when labor and other capital input costs increased by $50 \%$. The gross margin drop widened to $80 \%$ when an increase of $100 \%$ in labor and other capital input costs occurred. Breeder seed production in Uganda could not bear more than $25 \%$ increase in labor and other capital input costs. From a $50 \%$ increase in labor and other capital input costs, the gross margin became negative.

\subsection{Analysis of viability of groundnut seed production}

The benefit-cost ratio analysis showed the viability of groundnut seed production business with all ratios higher than 1 (Table 9). In most of the cases, EGS production schemes showed the highest BCR. Overall, the BCR ratio revolved around 3 for all seed classes and categories of seed producers.

\section{Discussion}

The high price of seed of improved and recently released varieties is one of the main factors hindering the majority of smallholder farmers from using new varieties to improve productivity in SSA, e.g. maize (Meughoyi 2018), rice (Ghimire, Huang, and Shrestha 2015) and subsequently be food secure. Having the right models that bring cost down and bring seed to scale is the focus of many studies in the seed sector. The paper analyzes different models of seed production by using CBA framework. It shows that seed cost can be brought down by leveraging the different opportunities within the seed sector. This would be a great way to boost seed of improved varieties to farmers, the majority of whom buy grain from open market for planting (McGuire and Sperling 2016). 


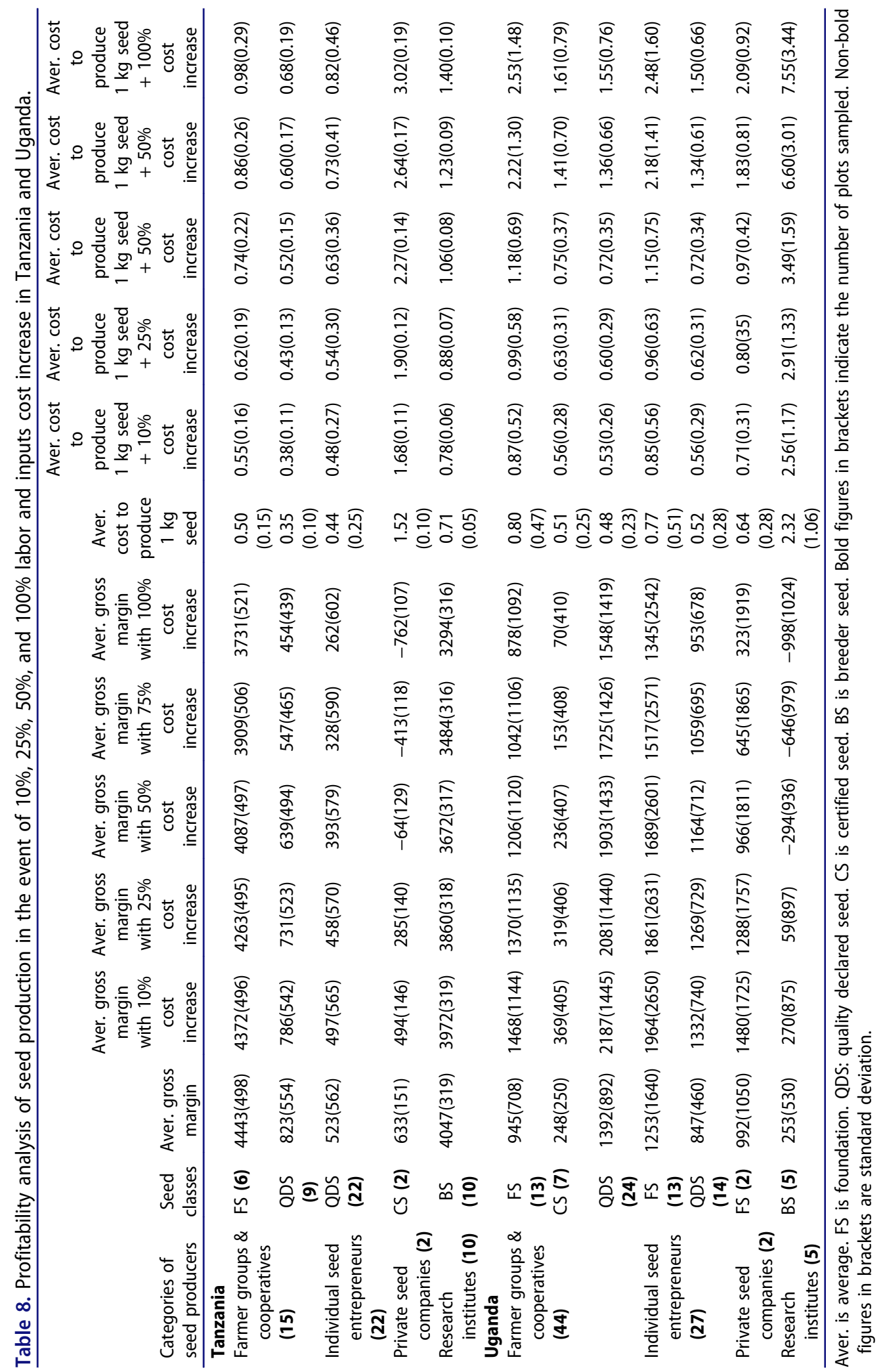


Table 9. Benefit-cost ratio (BCR).

\begin{tabular}{|c|c|c|c|c|c|}
\hline $\begin{array}{l}\text { Categories of seed } \\
\text { producers }\end{array}$ & $\begin{array}{l}\text { Seed } \\
\text { classes }\end{array}$ & $\begin{array}{c}\text { Benefit-cost } \\
\text { ratio }\end{array}$ & $\begin{array}{l}\text { Categories of seed } \\
\text { producers }\end{array}$ & $\begin{array}{l}\text { Seed } \\
\text { classes }\end{array}$ & $\begin{array}{l}\text { Benefit- } \\
\text { cost ratio }\end{array}$ \\
\hline Tanzania & & & Uganda & & \\
\hline \multirow{3}{*}{$\begin{array}{l}\text { Farmer groups and } \\
\text { cooperatives (15) }\end{array}$} & FS (6) & 8.04 & Farmer groups and & FS (13) & 3.19 \\
\hline & CS (0) & - & cooperatives (44) & CS (7) & 2.15 \\
\hline & QDS (9) & 3.09 & & QDS (24) & 4.08 \\
\hline \multirow{2}{*}{$\begin{array}{l}\text { Individual seed } \\
\text { entrepreneurs (22) }\end{array}$} & FS (0) & - & Individual seed & FS (13) & 3.71 \\
\hline & QDS (22) & 3.26 & entrepreneurs (27) & QDS (14) & 3.64 \\
\hline \multirow[t]{2}{*}{ Private seed companies (2) } & FS (0) & - & Private seed companies (2) & FS (2) & 2.38 \\
\hline & CS (2) & 1.45 & & $\operatorname{CS}(\mathbf{0})$ & - \\
\hline Research institutes (10) & BS (10) & 6.2 & Research institutes (5) & BS (5) & 1.34 \\
\hline
\end{tabular}

Bold figures in brackets indicate the number of plots sampled.

\subsection{Seed production close to farming communities}

Decentralized seed production, especially of non-hybrid legume crops, has been advocated as one of the effective ways to get seeds of new and improved varieties close to farmers in remote areas of developing countries (Setimela and Kosina 2004, 2004; Bishaw, Makkawi, and Niane 2009; Ojiewo et al. 2013). Usually, private seed companies and agro-dealer shops operate in areas that are easily accessible, while on the other hand, majority of the targeted smallholder farmers are in remote areas. The remote location and the small quantities of seed demanded by them, mainly on account of high prices arising from high production, marketing and distribution costs per unit of seed, make these market segments not lucrative to profit-driven seed entrepreneurs. Reaching these remotely located farmers requires alternative innovative seed production and distribution models (Bishaw, Makkawi, and Niane 2009). This is why community-level seed entrepreneur models (farmer groups, cooperatives, and/or individuals) are better bets to run seed business in their areas to serve their fellow seed/grain producers (Monyo and Varshney 2016).

Two classes of seed have been produced using close to community model, i.e. the foundation seed and the QDS. Foundation seed is the second level of EGS apart from the breeder seed. The latter class (breeder) is strictly under the control of research institutions and established private seed companies. For foundation seed, community seed producers have been used widely in the two study countries Tanzania and Uganda. These producers are usually under contract and under close supervision by research institutions and private seed companies that have contracted them.

The second class of seed that is produced closely within the farming communities is the QDS. Promoted by FAO since the early 1990s, the QDS is seed produced only by farmer groups or cooperatives or individual seed entrepreneurs at the community level with less stringent quality control compared with certified seed. Even its marketing and distribution is limited in the localities where it is produced. This seed production model has been implemented in the two study countries where the results from the analysis 
show that it is the cheapest seed class to produce and more affordable to smallholder farmers. For these reasons, this seed production model has been very successful in enabling farmers, in remote area to access quality seed that ensures superior yield compared with their own saved seed. This success has motivated development organizations in SSA to facilitate many farmers involved in production and marketing of QDS. It is not only successful in Tanzania and Uganda, as demonstrated in this study, but it has also been successful in India (Singh and Agrawal 2018).

These community foundation and QDS seed production and dissemination models are effective in significantly reducing the cost of producing, marketing, and distributing seed of groundnut in the two study countries. The reduced costs can easily be passed on to grain farmers in the form of more affordable seed prices. With more readily available and affordable quality seed, adoption of improved groundnut varieties is likely to improve (Elsheikh et al. 2018), leading to increased grain productivity and food security.

\subsection{Seed production by subcontracting}

Seed production through contract growers has gained popularity in East Africa. This model of seed production has the advantage of guaranteeing the market to contracted growers and assuring prerequisite volumes to the contracting seed producer/entrepreneur. Results from this study show that contracting seed production significantly reduces the cost of producing seed and, by extension, increases the profitability of seed production business to the contractor compared with when they produce seed themselves. These findings support earlier findings of more profitable ventures in contracting seed producers of legumes (Katungi et al. 2011; Pal et al. 2016; Omonona 2006), cereals like maize (Tsegaye 2012; Guei, Barra, and Silué 2011), and even fodder crops (Papendiek et al. 2016). Apart from enhancing profitability for growers, contract seed production has been shown to have the potential of supporting technology adoption and enhancing productivity that results in improved welfare of farmers in remote areas (Ragasa, Lambrecht, and Kufoalor 2018). Contracted farmers have opportunities to access more affordable productivity-enhancing inputs, as empirically demonstrated in Laos (Chaovanapoonphol and Somyana 2018).

However, some of the challenges that arise in contract seed production are associated with information asymmetry, such as failure to meet the quality standard when the contract grower is unable to meet minimum quality requirements (Samatha 2011). Seed "poaching" is also another challenge befalling this contracting model. This is where contracted growers sell the seed to seed companies other than the ones that contracted them. The main motivation for this kind of behavior from seed growers is that the alternative companies in most cases offer better prices than the predefined contract price. 


\subsection{Profitability of groundnut seed business, labor and inputs cost volatility, and seed price}

The profitability assessment of the groundnut seed business in the two study countries of East Africa shows that it is a worthwhile venture. It was only in a few cases where crop failure caused by drought led to negative gross margins. Otherwise, contrary to common perception that groundnut or legume seed business is not profitable, almost all studied cases returned positive gross margins with affordable retail seed price for QDS, certified seed, foundation seed, and breeder seed. The study showed that labor and other capital input costs are the main contributors to seed production cost structure and by extension they constitute a significant proportion of the seed retail prices. Because agricultural production input prices have been very volatile in East Africa, we investigated further on how sustainable the seed business might be in the event of labor and other capital input cost changes. To this end, we conducted sensitivity analysis of seed business profitability under five scenarios: $-10 \%, 25 \%, 50 \%, 75 \%$, and $100 \%$ cost increase. This analysis showed that even if the current other capital input costs were to increase by $50 \%$, groundnut seed production can still return positive gross margin in almost all cases studied. The risk of business failure sets in when the costs increase by $100 \%$.

Overall, seed production is a profitable business that has been demonstrated and widely reported for a variety of crops, including vegetables (Manjunatha and Venu Prasad 2012; Sarkar, Rashid, and Sarker 2013), cereals (Tsegaye 2012; Guei, Barra, and Silué 2011), legumes (Katungi et al. 2011), and root and tuber crops (Eyitayo, Anthony, and Theresas 2010; CIP 2011). This is a major prerequisite input for achieving food security in SSA.

\section{Conclusion}

Liberalizing the seed sector has been touted as the best option to lower the cost of production and to avail seed to smallholder farmers in developing countries at an affordable price. Affordable seed price plays an important role in achieving food security in the developing world. This study used primary data collected from Tanzania and Uganda to analyze the profitability of investing in groundnut seed production. The findings showed that the selling price of certified seed and QDS varied between 1 USD and 2 USD per kg and while that of EGS varied between 2 USD and 3.5 USD per $\mathrm{kg}$. On the other hand, seed production cost is estimated to be about 0.35 USD to 0.5 per $\mathrm{kg}$ for QDS and up to 2.3 USD per $\mathrm{kg}$ for breeder seed. Certified and QDS producers can earn between 250 USD and 1400 USD gross margin per ha. Furthermore, sensitivity analysis showed the stability and robustness of groundnut seed business against the fluctuation of labor and other capital 
input costs. Therefore, seed of improved groundnut varieties can be produced and availed to smallholder farmers profitably at an affordable retail price. We also find that different seed production models have a significant variation in costs across seed classes, and contract farming is the most profitable model of seed production in the two study countries. Overall, this study finds that in a well-functioning seed system, groundnut seed of improved varieties can be availed to farmers in remote communities at an affordable price and in a profitable manner. This would be a great step forward to sustainably build food security and nutritional health of the millions of smallholder farmers in SSA.

\section{Highlights}

- Legume seed, prerequisite to smallholder farming productivity in developing countries

- Groundnut seed can be availed at affordable price to farmers in remote communities

- Groundnut seed production proved viable business in the dryland agriculture

- Affordable seed price enhances rural livelihoods and community development

\section{Notes}

1. EGS include breeder and foundation seeds.

2. Breeder and foundation seed are normally classified as early generation seed. In this paper, we use breeder seed and foundation seed as synonymous of pre-basic seed and basic seed, respectively.

3. By quality declared seed (QDS), we mean a seed class produced and marketed at the community level by farmers and farmer organization with simplified quality control system and that uses certified seed as early generation seed. It is a decentralized community-level seed production and dissemination model.

4. These include self-individual/corporate production or contractual production arrangement.

\section{Acknowledgments}

The authors express their gratitude to the Bill and Melinda Gates Foundation (BMGF) for facilitating resources needed for this research through the Tropical Legumes III Project. We are grateful to the seed producers and other respondents who cooperated and helped to make this work to completion. Finally, we thank anonymous reviewers for their valuable inputs that enhanced the quality of this manuscript. 


\section{Disclosure statement}

No potential conflict of interest was reported by the authors.

\section{Funding}

This work was supported by the Bill and Melinda Gates Foundation (BMGF).

\section{References}

Akpo, E. 2013. “Analysing Seed Systems Performance the Case of Oil Palm in Bénin.” 211. $\mathrm{PhD}$ Thesis, Wageningen University.

Akpo, E., T. A. Crane, T.-J. Stomph, R. C. Tossou, D. K. Kossou, P. V. Vissoh, and P. C. Struik. 2014. "Social Institutional Dynamics of Seed System Reliability: The Case of Oil Palm in Benin." International Journal of Agricultural Sustainability 12 (3): 214-232. doi:10.1080/14735903.2014.909634.

Akpo, E., P. V. Vissoh, R. C. Tossou, T. Crane, D. K. Kossou, P. Richards, T.-J. Stomph, and P. C. Struik. 2012. "A Participatory Diagnostic Study of the Oil Palm (Elaeis Guineensis) Seed System in Benin." NJAS - Wageningen Journal of Life Sciences (60-63): 15-27.

Bishaw, Z., M. Makkawi, and A. A. Niane. 2009. "Seed Quality and Alternative Seed Delivery Systems." The Lentil: Botany, Production and Uses, . November: (1). 350-367.

Chaovanapoonphol, Y., and W. Somyana. 2018. "Production Efficiency of Maize Farmers under Contract Farming in Laos PDR." Kasetsart Journal of Social Sciences 1-6. doi:10.1016/j.kjss.2018.06.006.

CIP. 2011. Roadmap for Investment in the Seed Potato Value Chain in Eastern Africa. Lima, Peru: International Potato Centre.

Elsheikh, S. E., A. A. Hashim, H. H. Faki, and E. M. Elamin. 2018. "Impact Assessment of Adoption of Improved Varieties of Millet in North Kordofan State Sudan." Current Investigations in Agriculture and Current Research 4 (4). doi:10.32474/ CIACR.2018.04.000193.

Eyitayo, O. A., T. O. Anthony, and I. Theresas. 2010. "Economics of Seed Yam Production Using Minisett Technique in Oyo State, Nigeria." Field Actions Science Reports 4 (2010): 1-5.

FAO. 2010. Promoting the Growth and Development of Smallholder Seed Enterprises for Food Security Crops Best Practices and Options for Decision Making FAO. ed., Rome, Italy.

FAOSTAT. 2019. "Food and Agriculture Data." Accessed 1 January 2019. http://www.fao.org/ faostat/en/\#data/QC

Ghimire, R., W. C. Huang, and R. B. Shrestha. 2015. "Factors Affecting Adoption of Improved Rice Varieties among Rural Farm Households in Central Nepal.” Rice Science 22 (1): 35-43. doi:10.1016/j.rsci.2015.05.006.

Gittinger, J. P. 1982. Economic Analysis of Agricultural Project. 2nd ed. Baltimore: John Hopkins University Press.

GIZ. 2014. Farmers' Seed Systems. Bonn, Germany.

Guei, R. G., A. Barra, and D. Silué. 2011. "Promoting Smallholder Seed Enterprises: Quality Seed Production of Rice, Maize, Sorghum and Millet in Northern Cameroon." International Journal of Agricultural Sustainability 9 (1): 91-99. doi:10.3763/ijas.2010.0573.

Katungi, E., D. Karanja, D. Wozemba, T. Mutuoki, and J. C. Rubyogo. 2011. "A Cost-benefit Analysis of Farmer Based Seed Production for Common Bean in Kenya." African Crop Science Journal 19 (4): 409-415. 
Lanteri, S., and L. Quagliotti. 1997. "Problems Related to Seed Production in the African Region.” Euphytica 96 (1): 173-183. doi:10.1023/A:1002958325142.

Mangasini, K. A., M. L. Mwanahawa, M. G. Arbogast, and K. P. Neema. 2014. Socio-Economic Factors Limiting Smallholder Groundnut Production in Tabora Region, Dar es Salaam, Tanzania.

Manjunatha, G., and H. D. Venu Prasad. 2012. "Mode of Operation and Constraints of Hybrid Vegetable Seed Production under Contract Farming in Karnataka Mode of Operation and Constraints of Hybrid Vegetable Seed Production under Contract Farming in Karnataka.” Environment \& Ecology 39 (1A): 364-367.

McGuire, S., and L. Sperling. 2013. "Making Seed Systems More Resilient to Stress." Global Environmental Change 23 (3): 644-653. doi:10.1016/j.gloenvcha.2013.02.001.

McGuire, S., and L. Sperling. 2016. "Seed Systems Smallholder Farmers Use.” Food Security 8 (1): 179-195. doi:10.1007/s12571-015-0528-8.

Meughoyi, C. T. 2018. "Improved Seeds and Agricultural Productivity of Family Farms in Cameroon." In Building a Resilient and Sustainable Agriculture in Sub-Saharan Africa, edited by A. Shimeles, A. Verdier-Chouchane, and A. Boly, Cham, Switzerland. 15-32.

Monyo, E., and R. Varshney, eds. 2016. Seven Seasons of Learning and Engaging Smallholder Farmers in the Drought-prone Areas of sub-Saharan Africa and South Asia through Tropical Legumes, 2007-2014. Patancheru, India: International Crops Research Institute for the Semi-Arid.

Ojiewo, C. O., S. Kugbei, Z. Bishaw, and J. C. Rubyogo. 2013. “Community Seed Production.” In Workshop Proceedings, December 9-11. FAO, Rome \& ICRISAT, Addis Ababa, Ethiopia.

Omonona, B. T. 2006. "Cost and Returns to Contract Seed Production in Nigeria: Evidence from Osun State." Journal of Central European Agriculture 7 (3): 475-478. http://www.agr.hr/jcea/

Pal, G., R. Channanamchery, R. K. Singh, U. B. Kethineni, H. Ram, and S. R. Prasad. 2016. "An Economic Analysis of Pigeonpea Seed Production Technology and Its Adoption Behavior: Indian Context." Scientific World Journal 2016. 1-7.

Papendiek, F., V. E. Tartiu, P. Morone, J. Venus, and A. Hönig. 2016. "Assessing the Economic Profitability of Fodder Legume Production for Green Biorefineries - A Cost-benefit Analysis to Evaluate Farmers Profitability." Journal of Cleaner Production 112: 3643-3656. doi:10.1016/j.jclepro.2015.07.108.

Ragasa, C., I. Lambrecht, and D. S. Kufoalor. 2018. "Limitations of Contract Farming as a Pro-poor Strategy: The Case of Maize Outgrower Schemes in Upper West Ghana." World Development 102: 30-56. doi:10.1016/j.worlddev.2017.09.008.

Samatha, M. 2011. "Prospects and Challenges of Peace-building." History and Sociology of South Asia 5 (1): 31-47. doi:10.1177/223080751000500102.

Sarkar, M., M. Rashid, and M. Sarker. 2013. "Contract Farming in Tomato Seed Production in Rangpur District of Bangladesh: A Financial Analysis." Progressive Agriculture 22 (1-2): 169-179. doi:10.3329/pa.v22i1-2.16478.

Setimela, P. S., and P. Kosina. 2004. Strategies for Strengthening and Scaling up Communitybased Seed Production. Mexico City, Mexico.

Singh, R. P., and R. C. Agrawal. 2018. "Improving Efficiency Of Seed System By Appropriating Farmer's rights in India through adoption and implementation of policy of quality declared seed schemes in parallel.” MOJ Ecology \& Environmental Sciences 3 (6): 387-391.

Tsegaye, D. 2012. "Profitability of Contractual Bread Wheat Seed Production in Mecha District of Amhara Region, Ethiopia." Journal of Central European Agriculture 13 (1): 142-149. doi:10.5513/JCEA01/13.1.1026. 